\title{
New Teaching Mode Practice of Basic English Course in Flipped Classroom
}

\author{
Xie Huiying \\ City College of Dongguan University of Technology, Dongguan, China \\ flsxhy@163.com
}

Keywords: Basic English; flipped classroom; traditional classroom

\begin{abstract}
As a core course for freshmen and sophomores of English major, Basic English teaching still exists lots of complexes such as the restrained teaching mode, little teaching duration, less interaction between teachers and students and unsatisfied teaching results. In this paper, the author has conducted a comparative research between two classes and has discussed whether the current Basic English teaching situation can be improved by the combination of flipped classroom and information technology, whether the traditional teaching method will be replaced or not and the advantages of flipped classroom. Turns out, this flipped classroom idea can perform an efficient work in improving teaching results, students' English levels and their self-learning ability and logically-thinking ability to truly realize the "student-centered English teaching". On the other side, there are some potential problems in the practice process, which needs us to keep improving this teaching method to better realize the "learning and applying integration" teaching goal and cultivate more students of highly educated English levels.
\end{abstract}

\section{Introduction}

There comes a more varied way for people to obtain information and knowledge with a rapid development of modern information technology. This attributes to a wider learning method of people especially shown as their needs for online lessons, which has made the flipped classroom based on online technology being a hot issue in education field. The flipped classroom has brought a big reform on the traditional learning method. Teachers no more have the need to explain the plain definitions and knowledge but organize students into practical tasks by leading them independently to learn the related information online before the class to make them easily understand things deeper. This transform involves students into the class as organizers and participants and set the learning process outside the classroom and knowledge understanding in the classroom to make students better master knowledge and deepen mutual communications between students and teachers.

The disadvantages of traditional classes have been greatly improved by the flipped classroom, thus there has prompted a new teaching mode on modern information technology to better satisfy the teaching goals. Researchers have devoted themselves into the feasibility research and actual application of flipped classroom in years. Referring to the current research, there exists an imbalance between science \& engineering and language subjects with less having been done on the latter. As for the researches on English language, more studies are conducted on the flipped classroom of College English teaching and little are conducted on English major courses, such as the listening and translation ones. Therefore, this paper is to study an efficient teaching mode for the Basic English course in flipped classroom.

\section{Current Teaching Situation of Basic English}

Basic English course, also known as Intensive English and Integrated English, have been set as a primary course for freshmen and sophomores of English major in most colleges to conduct an overall and basic language using training in listening, speaking, reading, writing and translation aspects. In this way, it can form a firm foundation for the third and fourth year's study. The current Teaching Syllabus for English Majors (enforced from 2000) has officially acknowledged its primary 
importance of full teaching duration, efficient class hours and large credits portion. This outline also points out a teaching transform from teacher-oriented to students-oriented mode by positively combining with modern information methods.

As for now, the traditional teaching method still holds the top usage that teachers blindly input knowledge by explaining the texts from grammar to the translation part with fully and only attention on words study, sentence by sentence translation, grammar points and after-school exercises. During this process, there is little opportunity for students to experience the mutual communication with teacher and the process of putting forward problems, analyzing and solving them. The only work they need to do is to write down lots of notes and to act as the knowledge receiver. To generally sum up, the current teaching mode is still combined with the teachers' one-way output and the students' fully input. Most teachers are not adequate in positively leading and evaluating students, and fail to live up to the teaching goals.

\section{Feasibility of Flipped Classroom Mode in Basic English Teaching}

\subsection{Rationality of flipped classroom}

Bloom's Taxonomy points out that the cognitive process is identified as six levels: remembering, understanding, applying, analyzing, evaluating, and creating (Williams, Beth: 2013). Traditional teaching method is made up by three parts - pre-class learning, in-class input and after-class comprehension, which can only realize the first two cognitive processes. These two are also known as the low-end targets. The rest four cognitive processes can only be completed through after-school work, which largely relies on students' self-discipline. Also combined by three parts: pre-class, in-class and after-class, the flipped classroom is equipped with rather different features of teaching contents and targets from the traditional one. Before the class, students are going to watch the videos made by the teacher to study the related basic knowledge. During the whole class, the teacher will discuss with the students by analyzing and solving the problems to realize an efficient comprehension of the teaching content. After the class, the teacher will assign tasks for students according to their in-class performance. With this, an effective flipped classroom is completed. It turns out the flipped classroom fits to be put into use in Basic English teaching to help students overall complete the cognitive process in the class.

\subsection{Flipped classroom satisfies students' needs}

Given the truth that there exist large differentials among English major students, the single in-class teaching is bound to fail to live up to every student's study need. Although the teachers are aware of the importance of combining study and practice together, they have to choose the one-way knowledge input to complete the heavy teaching tasks and keep explaining the basic knowledge in order to match the low-performed students. As for the well-performed students, this mode cannot satisfy their learning needs on one side, no opportunity for them to effectively practice their learning results on the other side. Contrary to the expected result, the low-performed students are not receiving learning results for that they are busy in writing down notes to memorize after class without deeper thinking on knowledge. Interests and motives will disappear with the repeating, dull learning pace.

Changes will happen in flipped classroom. Before the class, students can effectively take use of the videos based on their own English levels to get a general master of class content and raise their problems. In the class, students are free to put forward their own problems and solve them together to give a feedback to the teacher of their learning performances. Students with good performances can conduct a deeper study on the basic learning. Besides, students of low levels can repeatedly study the pre-class video to reach a general master of the in-class content so as to positively take part in the discussion rather than one-way note writing. Under this mode, study for English major students will become easier and more interesting. 


\section{Case Study of Flipped Classroom in Basic English Teaching}

\subsection{Teaching results comparative analysis between traditional and flipped classroom}

The writer conducted traditional teaching method on the class of 49 students and flipped classroom method on the class of 51 students. In this experimental practice, she has conducted flipped classroom mainly centering on the background information, vocabularies and key grammar points. Taking Subjunctive Mood in the following text "Fun. Oh, Boy. Fun. You Could Die From It" as a practice example, the writer conducted a comparative analysis on both classes learning results (Class 1: traditional teaching way; Class 2: flipped classroom way). The following Table 1 shows the teaching design.

Table 1 teaching content design of subjunctive mood

\begin{tabular}{|c|c|c|c|c|}
\hline No. & & Pre-class & In-class & After-class \\
\hline \multirow[t]{2}{*}{ Class 1} & teacher & $\begin{array}{l}\text { 1. Assign the } \\
\text { preparations for the } \\
\text { next class } \\
\text { 2. Prepare the } \\
\text { demonstrative PPT }\end{array}$ & $\begin{array}{l}\text { Explain the } 8 \text { concepts of } \\
\text { subjunctive mood in details. }\end{array}$ & $\begin{array}{l}\text { Assign exercises } \\
\text { of Test } 1 \text { and } \\
\text { correct students' } \\
\text { homework }\end{array}$ \\
\hline & students & $\begin{array}{lr}\text { Learn the } & \text { related } \\
\text { knowledge } & \text { in } \\
\text { advance } & \text { by } \\
\text { themselves } & \end{array}$ & $\begin{array}{l}\text { Listen to the teacher's lecturing and } \\
\text { answer the raised questions }\end{array}$ & $\begin{array}{l}\text { Complete the } \\
\text { exercises of Test } 1\end{array}$ \\
\hline \multirow[t]{2}{*}{ Class 2} & teacher & $\begin{array}{l}\text { 1. Make and send the } \\
\text { pre-class video to } \\
\text { students based on the } \\
\text { real students' levels; } \\
\text { Assign Test } 1 \text { to them. } \\
\text { 2. Track students real } \\
\text { learning situation and } \\
\text { design the class } \\
\text { teaching targets }\end{array}$ & $\begin{array}{l}\text { 1. Further explain the related } \\
\text { knowledge according to the } \\
\text { emerging problems from Test } 1 \text {. } \\
\text { 2. Organize in-class activity: select } \\
\text { the sentences with subjunctive } \\
\text { mood and analyze them; whole } \\
\text { class discussion on questions raised } \\
\text { by students }\end{array}$ & $\begin{array}{l}\text { 1. Publish } \\
\text { upgraded Test } 2 \\
\text { online } \\
2 . \text { timely offer } \\
\text { feedback and } \\
\text { instructions for } \\
\text { students on the } \\
\text { results of Test } 2 \text {. }\end{array}$ \\
\hline & students & $\begin{array}{l}\text { Independently watch } \\
\text { and learn the } \\
\text { teaching video and } \\
\text { complete Test } 1 \text {. }\end{array}$ & $\begin{array}{l}\text { With the mastered knowledge, } \\
\text { actively take part in the class } \\
\text { activities and perform effective } \\
\text { output exercises. }\end{array}$ & $\begin{array}{l}\text { Overcome the } \\
\text { difficulties and } \\
\text { maximize the } \\
\text { study results } \\
\text { relying on the } \\
\text { teacher's } \\
\text { feedback }\end{array}$ \\
\hline
\end{tabular}

The writer explained the 8 concepts of subjunctive mood according to the actual language usage as follows: the basic sentence patterns, implied conditional sentences, subjunctive mood conditional sentences of mixed time, inverted sentences of subjunctive mood—conditional sentences without if , subjunctive mood employment in subordinate clauses, It's (high/about) time that clause, wish/if only/as if clauses and blessings in good or bad will clauses. In the preparation work, the researcher completed the PPT, 8 videos for each concept and related Test 1 for students to practice their learning points in advance. With the work done, they are ready to be uploaded to the SPOC network for students.

During the teaching of Class 1, there are only $46.9 \%$ students having accomplished the preparation work for the class. Most of the students are just listening to and writing down the teacher's explanations without any question. After class, most students turned to teacher mostly via phone calls, Wechat and QQ for help.

Things are quite different in Class 2. All students are able to accomplish the learning task. The following table 2 shows the detailed learning performance. 
Table 2 statistics of Class 2 completing the pre-class tasks

\begin{tabular}{|c|l|c|c|}
\hline No. & \multicolumn{1}{|c|}{ Video Contents } & CTR & $\begin{array}{c}\text { Accuracy rate } \\
\text { of Test 1 }\end{array}$ \\
\hline 1 & The basic sentence patterns & 53 & $98.6 \%$ \\
\hline 2 & The implied condition sentences & 96 & $68.6 \%$ \\
\hline 3 & Inverted sentences_conditional sentences without if & 88 & $72.3 \%$ \\
\hline 4 & Subjunctive conditional sentences of mixed time & 62 & $88.5 \%$ \\
\hline 5 & Employment in subordinate clauses & 93 & $76.8 \%$ \\
\hline 6 & Employment in It's (high/about)time that clause & 76 & $92.2 \%$ \\
\hline 7 & Employment in “wish/if only/as if” clauses & 81 & $86.9 \%$ \\
\hline 8 & Employment in good or bad will blessing clauses & 58 & $96.4 \%$ \\
\hline
\end{tabular}

Based on the self-learning situations of students, the teacher mainly discussed the common problems and questions from students centering on the second, third and fifth concept in the table as the accuracy rate are relative low than others. Separating students into several study groups, the teacher requires members in every group to study together and complete new exercises. After the group discussion, they also are required to select one student out to further explain the exercises for the rest class. With a further practice of concept 2, 3 and 5, the students can already better understand the subjunctive mood in the text without the teacher's guidance and sentence-by-sentence explanation.

After the class, students in Class 1 should finish Test 1 that have been done by Class 2 before the class to evaluate their comprehension of class content. While Class 2 needs to finish the Test 2 with upgraded difficulty and enhance their language using ability by studying the Test 2 feedback from the teacher on SPOC. Results turn out to be that the average points of Class 1 reaches 78.6 with accuracy rate lower than $60 \%$ in concept 2, 3, 5 and 7 while the average points reaches 92.6 in Class 2. Obviously here turns out to be a big difference in class learning of two classes and also in final examination that the average score of Class 2 is 10 points higher than Class 1 . To conclude, flipped classroom adapts to the Basic English teaching and performs an effective role in improving students' in-class participation and study interests.

\subsection{Advantage analysis of flipped classroom mode}

Throughout the whole research, students in flipped classroom state that this new mode acts as an effective method in their language learning process in both their self-study ability and motivation. There are three explicit advantages in upgrading current Basic English teaching.

First, the fundamental knowledge learning will be conducted before the class, by which the class time will be available for students and teachers focusing on the deep understanding of difficulties and major concepts. The pre-class work benefits both the good level students and lower level students. The good ones are able to find out their own puzzles on the learning content in advance, and the others can learn the contents for several times to better understand the class content and avoid the dilemma of behind the whole class schedule. From the teacher's vision, she will be allowed to better perform as an instructor and leader of the class to fully assist students understand and practice the language rather than the knowledge explainer. Take these two classes as an example, students in Class 2 in the flipped classroom learns better and faster than those in Class 1.

Second, flipped classroom mode can provide a more functional environment for teachers and students where they can communicate with each other and form a closer relation. There used to be a mere process of knowledge transforming from teachers to students lacking efficient mutual communication under the traditional class mode. Circumstance has changed under the flipped classroom mode. With students acquiring the basic information of the class content, teachers are free to conduct a face-to-face discussion with students in class, solving their problems and questions. This change benefits a lot for a closer relation between teachers and students.

Third, this flipped classroom helps students to foster a well study habit and strong interest. It is universally acknowledged that one person's English ability is related to his self-learning ability and awareness. The traditional class arrangement at college is rather tight and abundant which needs 
students to do lots of work in their spare time. For the freshmen and sophomores, they are more familiar with the teacher explaining to them in the class rather than self-learning. Besides, students at this stage are not equipped with mature language using skills. Without effort in the daily study, knowledge will become harder for them to study in the class. Circumstances will turn out rather unpleasant when time passes by that students are lazy to learn by themselves and dull to listen to the teacher's lecture. The introduction of flipped classroom brings a new life to English teaching. In the primary stage of Class 2, there are few hit, and less than 5 students repeatedly learn the teaching video. Time passing by, the hit rate of some videos increases to $260 \%$. More and more students are used to learning in advance to keep their pace with the whole class. The study atmosphere heats to an unprecedented height. Students in the class prefers to express their opinions and show their problems with classmates and teachers, which also motivates other less-talking students positively to devote into the whole class discussion. For now, the Basic English course has been regarded as the 'three most' course: the most beneficial, attractive and self-expressing course.

\section{Conclusion}

The rapid development of modern technology offers a solid and great foundation for the flipped classroom implement. This introduction has formed a refreshing and ascensive teaching mode comparing with the traditional pattern. This paper has proved the feasibility and efficiency of flipped classroom in Basic English teaching on both theoretical and practical aspect. This teaching reform can change the old and lazy learning atmosphere of students into a positive and effective one, and will assist to further realize a 'learning and applying integration' reform for elevating teachers teaching skills and students' critical thinking and comprehensive learning ability. Still, this teaching mode is at its experimental stage facing lots of difficulties, including teachers' qualities, teaching content choosing, effectiveness of the learning videos and role switching of teachers and students. The writer will conduct further research of this mode, explore more potential advantages and avoid the disadvantages as many as possible to maximize its effectiveness and realize a mutual progress for both teachers and students.

\section{Acknowledgements}

This work was supported by Higher Education Teaching Reform Project of City College of Dongguan University of Technology in 2017, 2017yjjg007

\section{References}

[1] Bergmann, J \& Sams, A. Flip Your Students’ Learning [J]. Educational Leadership,2013.

[2] English group in Teaching Steering Committee of foreign language major in colleges. Teaching Syllabus for English Majors [M]. Beijing: Foreign Language Teaching and Research Press, 2000.

[3] Junyue Chang, Xue Jin. Current Problems in the Required Course for English Major 'Essential English’ Teaching Content and Related Reform Proposition [J]. Foreign Language Research, 2012.

[4] Lan Ke. Application of Flipped Classroom in English Major - A Case Study on Essential English Teaching [J]. Asia-Pacific Education, 2016.

[5] Williams, Beth. How I Flipped my Classrooms[C]. Norfolk, NE: NNNC Conference, 2013. 